\title{
Analysis of China's Trade Relations and Its Impacts on the Guinean Economy
}

\author{
Ly Tibou, Fangmiao Hou \\ Beijing Forestry University, Beijing, China \\ Email: tibouamadou@yahoo.com
}

How to cite this paper: Tibou, L. and Hou, F.M. (2017) Analysis of China's Trade Relations and Its Impacts on the Guinean Economy. Open Access Library Journal, 4: e3482.

https://doi.org/10.4236/oalib.1103482

Received: February 27, 2017

Accepted: May 22, 2017

Published: May 25, 2017

Copyright $\odot 2017$ by authors and Open Access Library Inc.

This work is licensed under the Creative Commons Attribution International License (CC BY 4.0).

http://creativecommons.org/licenses/by/4.0/

\section{(c) (i) Open Access}

\begin{abstract}
In this paper, we examine China's trade relations in Africa with particular emphasis on Guinea Republic, West Africa. The study also explores China's involvement in the Guinean economic sector, its impacts on the Guinean economy and the challenges these trade relations currently face. To attain this goal, we carry out a scientific review of published literature. Using this approach, we observed that China's trade relations in Guinea and Africa in general are on an upward trend where China mainly imports primary products and Guinea finished products. We also observed that these trade agreements have facilitated Guinea's participation in global international markets and have boosted the local economic growth and social development. Therefore, upscaling of China from a mere primary products importer to finished products importer, will go a long way to improve on the socioeconomic development and eradication poverty in rural Africa and Guinea in particular.
\end{abstract}

\section{Subject Areas}

Development Economics, Economic System, Economics of Law

\section{Keywords}

China-African Cooperation, Guinea, Economic Growth, Social Development, Poverty Alleviation, Trade Relations

\section{Introduction}

One of the most remarkable economic events in the last decade is the economic transformation of China and its integration into the world trading system. Its gross domestic product per capita (GDP) increased at an average of $10.88 \%$ since 1989 and it is predicted to become the world's first economy in 2024 (OECD, 2015) [1]. According to Winters and Yusuf (2007) [2], China will grow at an annual average rate of $6.6 \%$ from 2005 to 2020 . In this way, China's share of 
world GDP was $13.71 \%$ in $2004,16.86 \%$ in 2015 and is projected to rise to $18.89 \%$ by 2020 , exceeding United States' share (OECD, 2015). Similarly, Rodrik (2006) [3] observed that China's economy has expanded by leaps and bounds, at historically unprecedented rates that few economists would have found plausible or feasible ex-ante.

The rapid growth of China has also been paralleled by its emergence as a major trading power in the world. China's exports have been growing over the past decade, except in 2009 when financial crisis and global economic downturn slowed down global trade. Apart from being the most populous country, China has also become the largest manufacturing economy and the largest exporter in the world (Statista, 2014) [4]. For instance, China's share of growth in world export of goods and services was $7.8 \%$ between 1995 and 2003, and is projected to attain $11 \%$ between 2005 and 2020 as well as being the largest contributor to import growth in the world (Statista, 2014) [5].

According to Weizhong (2008) [6], trade between China and Africa stood at US\$935 million in 1990, which increased to about US\$ 55.5 billion in 2006. During the year 2014, trade between Africa and China increased by $8 \%$ from the previous year to US\$ 186.6 billion. This included Chinese imports from Africa equaling US\$108.9 billion and Chinese export totaling $\$ 77.7$ billion (Weizhong, 2008) [6].

Apart from the growing volume of trade between Africa and China, the composition of its exchange is also a matter of concern. Africa imports mainly manufactured products and exports mainly raw materials. This model is the same with the other developed countries. The perpetuation of this model raises questions about Africa's industrialization prospects and development as a whole (Figure 1).

Kaplinsky and Morris (2007) [7] provide evidence of China's negative impact on sub-Saharan Africa in the world of the textile and clothing industries.

Furthermore, Ajakaiye (2006) [8] equally found that instead of Sino-African trade partnership lending assistance to the transformation and development process in Africa, it actually truncates it. This notwithstanding, there is potential positive impact on Africa's terms of trade, if the prices of its imports fall, while

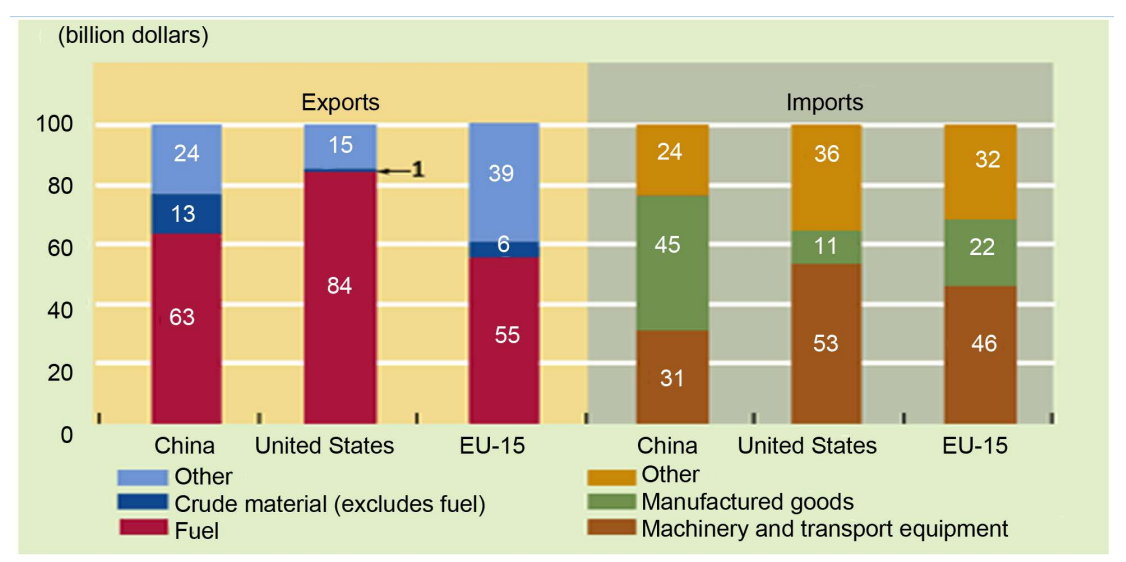

Figure 1. Africa trade pattern. Source: UN Comtrade database. 
those of its exports rise (Goldstein et al., 2006) [9].

China's share of imports (essentially manufactured goods) to Guinea grew substantially between 2010 and 2015, whereas exports (few primary products) to China have not changed hence aggravating Guinean's trade deficit. This trade pattern undermines Guinea's industrial sector and locks Guinea in primary activities. In general, Chinese goods are having a positive impact on consumers, especially amongst the rural and urban poor. For instance imported motorcycles from China are found to be complementing the production of taxi services in both urban and rural settings. Thus, Chinese motorbikes are increasing the supply of taxi services, creating jobs, and generating revenue.

It is necessary therefore to intensify empirical research on this economic relationship which presents both opportunities and challenges for African economies that reflect deepening relations with China.

From this study, through the review of scientific literature, we examine China's trade relations in Africa with particular emphasis on Guinea Republic, West Africa. The study is divided into two sections with the first looking at China's trade relations with Africa. In the second section, we explore China's trade relations and agreements with the Republic of Guinea. Here we look at trade relations (imports and exports goods) from China to Guinea and Guinea to China. This will allow us to maximize the benefits and minimize the costs of subSaharan African (SSA) economies in general and, Guinea especially with China.

\section{China's Trade Relationship with Africa}

China's relations with Africa have increased over the last decade. Trade between China and Africa stood at US $\$ 935$ million in 1990, and then increased to US $\$ 10.6$ billion in 2000 and US\$ 55.5 billion in 2006. During the year 2014, trade between Africa and China increased an 8\% from the previous year to US\$186.6 billion. This included Chinese import from Africa equalling US $\$ 108.9$ billion, and Chinese export totalling $\$ 77.7$ billion (Figure 2). In 2015 China Africa trade had a total value of 300 Billion US Dollars. This growth is explained by the crude oil bill, mostly imported from Angola. China is also seeking to raise the amount to 400 billion dollars by 2020, said Yang Fuchang, a former deputy foreign minister, at the fourth CAIF opening session.

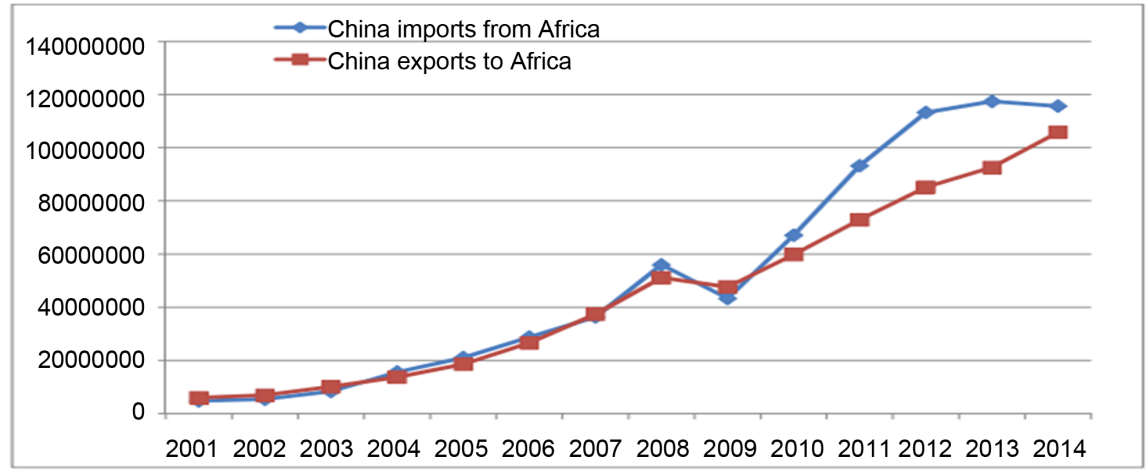

Figure 2. China Africa trade value source: ITC Trade map (2015). 
(Ali Zafar 2007) [10] show that Trade between China and Africa in 2006 totaled more than $\$ 50$ billion, with Chinese companies importing oil from Angola and Sudan, timber from Central Africa, and copper from Zambia. Demand from China has contributed to an upward swing in prices, particularly for oil and metals from Africa, and has given a boost to real GDP in Sub-Saharan Africa.

At the same time, however, strong Chinese demand for oil is contributing to an increase in the import bill for many oil-importing Sub-Saharan African countries, and its exports of low-cost textiles, while benefiting African consumers, is threatening to displace local production. China poses a challenge to good governance and macroeconomic management in Africa because of the potential Dutch disease implications of commodity booms. China presents both an opportunity for Africa to reduce its marginalization from the global economy and a challenge for it to effectively harness the influx of resources to promote poverty-reducing economic development at home.

In 2014, crude oil accounted for $44.12 \%$ of China's imports from Africa. Crude oil, minerals ores, tobacco and wood contribute over $90 \%$ China's imports from Africa. Africa's export profile to China remains undiversified and concentrated in few raw materials, thus presents huge economic vulnerabilities in light of the slowing down of China's economy. So in 2005 China provided duty-free access for 190 items from 25 least developed Sub-Saharan African (SSA) countries. Three year later, duty-free access was extended to 454 items from 31 SSA LDCS.

The impact of China on African economies has been diverse, depending in part on the sectorial composition of each country's production. Overall, China's increased engagement with Africa could generate important gains for African economies. One overriding consideration is that reaping the full benefits from Chinese trade and investment will require substantial improvements in governance in African economies. (Mary-Françoise Renard 2011) [11].

As a benchmark, by performing the same analysis on other major African trade partners: France, Germany, UK, and USA. Data from 53 African countries in 1996-2009 show that only China is consistently willing to import more from African countries with a lower governance standing. By doing so; China fills a gap left open by the other major world economies, and might even play a key role in the future development of Africa. (Paul de Grauwe, Romain Houssa 2012) [12]

Consistent with the principle of non-interference governing China's foreign engagement and to south-south cooperation's core principle of mutually beneficial exchange, preferential market access is not conditioned on institutional reform and is extended to all least developed SSA countries with which China has diplomatic relations.

Such preferential market access intended to increase the range of Africa's exports to China and address the negative trade balance with a number of countries. There is a lack of convincing evidence demonstrating that the preferential trade arrangement has helped preference-eligible countries gain competitive 
edge over other exporters into the Chinese market (Catherine Yap Co Ralitza Dimova 2014) [13]. In other words, the extent to which this will translate into narrowing the trade gap between China and Africa is yet to be captured.

Since 2016, President Xi Jinping has successively visited Egypt and the League of Arab States, and other leaders of the Chinese government and the Central Party Committee such as the Chairman of the Standing Committee of the National People's Congress Zhang Dejiang, the Chairman of Chinese People's Political Consultative Conference Yu Zhensheng successively visited African countries.During these visit, both Chinese and African leaders reviewed friendship, discussed cooperation, sought cooperation and constantly injected strong impetus to the China-Africa trade and economic cooperation. (Ministry of commerce people's Republic of China) [14]. Those High-level visits indicated directions for China-Africa trade and economic cooperation.

\subsection{Some China Africans Case}

\subsubsection{Cameroon}

China's share of imports (essentially manufactured goods) to Cameroon grew substantially between 2001 and 2005, whereas exports (few primary products) to China have been declining and aggravating Cameroon's trade deficit. This trade pattern would undermine the industrial sector and lock Cameroon in primary activities. A large proportion of surveyed consumers is sensitive to the origin of goods and consumes Chinese goods, in spite of quality concerns. Imported motorcycles from China are found to be complementing the production of taxi services in the main cities." ( Sunday Aninphah khan, Francis Menjo Baye, Godwill K 2008) [15].

\subsubsection{Mauritius}

According to (Vinaye Ancharaz and Verena Tandrayen-Ragoobur 2010) [16] their finding in The impact of Sino-Mauritius trade relationship suggest that small firms and those in such sectors as garments, footwear and furniture have experienced a loss of market, and have consequently downsized on the other and Cheap imports from china have certainly benefited consumers. But the poor quality or hazardous nature of Chinese products constitutes a potential loss to consumers.

\subsubsection{South Africa}

To account a differential effects, (Lawrence, Edwards, Jenkis, Rhys 2013) [17] [18] draws on a database of 44 manufacturing industries covering the period 1992-2010. They use Two approaches ( a chenery type decomposition and econometric sestimation) to evaluate the impact of Chinese trade on prices, production and employment in South African manufacturing. They found, Chinese penetration of the South African market is shown to have increased rapidly over the past decade, in part due to displacement of imports from other countries, but more importantly at the expense of local production. Exports of manufactures to China did not add significantly to industrial growth in South 
Africa, whereas labour-intensive industries were particularly badly affected by Chinese imports implying that the negative impact on employment was more than proportional to the output displacement. However, we also find evidence that Chinese imports contributed towards lower producer price inflation in South Africa, which in turn will have moderated increases in consumer prices and helped to curtail production cost increases.

\section{China's Trade Relations in Guinea}

\subsection{General Commercial Situation of Guinea}

Guinea is the 124th largest export economy in the world and the 133th most complex economy according to the Economic Complexity Index (ECI). In 2014 Guinea exported $\$ 3.07$ billion and imported $\$ 3.44$ billion, resulting in a negative trade balance of $\$ 369$ million. In 2014, Guinean GDP Guinea was $\$ 6.62$ billion and its per capita GDP was $\$ 1.22$ thousand. The main exporting countries of Guinea are: Gold (972 million), Crude Oil Production (841 million) Aluminum Ore (\$739 million), Postage Stamp (187 million)

The main exports of Guinea are Gold ( $\$ 972$ million), Crude Oil Production (\$841 million), Ore Aluminum (\$739 million), Stamps (\$187 million) and Coconut, Brazil nuts, 4 million) using the 1992 revision of the HS (Harmonized System) classification. Its main imports are Refined Petroleum (\$719 million), Rice ( $\$ 286$ million), Raw Sugar (\$103 million), Packaged Drugs (\$81.8 million) and Wheat Flour (\$73.9 million). The top destinations in Guinea for export are South Korea (\$660 million), India (\$541 million), Ghana (\$424 million), United Arab Emirates ( $\$ 389$ million) and Spain ( $\$ 162$ million). The top import origins are China, Netherlands India ( $\$ 271$ million), France ( $\$ 171$ million) and Belgium Luxembourg (\$121 million). Guinea is adjacent Côte d'Ivoire, Guinea-Bissau, Liberia, Mali, Senegal and Sierra Leone.

The structure of the bill for imports of Guinea show that the dominance of the France as a long-term first partner for import of Guinea has not much changed over the past 20 years while those of China and the Netherlands increased gradually. On the other side, imports trade between Guinea and China have increased quite quickly, which puts China at the first position of Guinea partner for the import (Figure 3).

\subsection{Sino-Guinea Trade Pattern}

China's trade pattern with Guinea is similar to some African countries. The Sino-guinea trade relations knew a rapid increase in the volume of trade over the past few years, largely due to a surge in imports from China, as exports to China are on the decline.

\subsection{Guinea Export to China}

Guinea's exports to China are still small but growing gradually. The major exports are aluminium ore, iron ore, raw wood, animal origin product and metals. An analysis of the trends and patterns of Guinea's exports growth to 


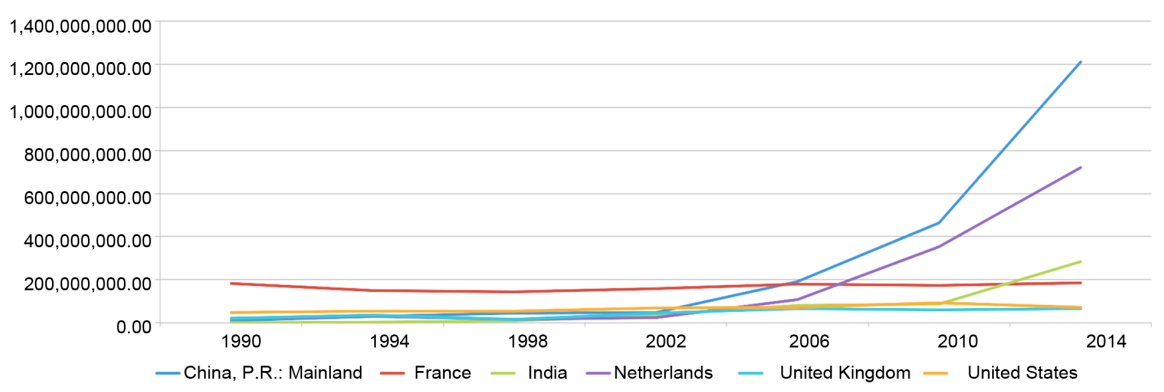

Figure 3. Guinea import partners. Source: UN comtrade database.

China suggests many impacts: Aluminium ore exports to China are still a small proportion of Guinea's total export market constituting only $1.7 \%$ in 2014 $(\$ 12.3 \mathrm{M})$ by the same time, China total import represent $\$ 1.48$ Billion which is $46 \%$ from Australia and only $0.83 \%$ from Guinea. Guinea's aluminium ore is valued highly because of its quality and is an input in high quality aluminium. And also guinea is known to have the highest aluminium ore reserve in the world.

In the iron ores sector, Guinea's exports to China rose from $0 \%$ of total iron ores exports to $100 \%(\$ 18.2 \mathrm{M})$ in 2014 and the among is expected to rose de next year.

The export of timber to China began in 2006 with a $2 \%$ share $(\$ 72.2 \mathrm{~K})$ on the Guinea's worldwide Wood export. Two years later, the export to China will represent $68 \%(\$ 17.3 \mathrm{M})$. In 2009 , while the share of exports to China not that can declined $62 \%$, but the amount of the export has considerably fallen ( $\$ 3.96$ M) due to the political situation of that time. And in 2010 China reached $91 \%$ of the export of wood of Guinea worldwide with a record amount of $(\$ 47.6 \mathrm{M})$. And since 2012 China represents $100 \%$ of exports of wood of Guinea worldwide.

The proportion of the export of products of animal origin to China was always very unstable, although in general the value of exports increased from $\$ 3 . \mathrm{K}$ in year 2000 to $\$ 4.3 \mathrm{M}$ in 2014. And its exports are largely composed of net fish, not net of fresh fish, processed fish, shellfish and other animals. The fishing sector remains underdeveloped, and fishermen have also remained poor.

Overall, Patterns of Guinea's major export products and the export trend to China suggest that the trading relations especially in allowing Guinea's participation in the international market and also in supporting economic activities have been beneficial to the country through (overall development and employment). The Export trading majorly has been on primary commodities.

\subsection{Guinea Import from China}

Major Guinea's imported products from China are shoes in rubber, phone, motorcycle, electric transformer, pure light cotton, ceramic, packaged drug, battery, iron and steel. In term of value the leading imports are machines followed by textiles, metals, transport, footwear and headgear, ceramic product, drug and chemical, plastic and rubber, various and article in paper. Guinea also locally manufactures shoes in rubber thus the imports from china is in direct competi- 
tion with local manufacturing industry. Guinea's competitiveness in footwear is much lowers than China that has gain a large comparative advantage in the last 20 years. Guinea's trade with China presents an opportunity for wide range of goods in the market. However Guinea's market is one of the markets where counterfeit products are widely found in the market, because event those drugs are not spared.

The Bill of Commerce of Sino-Guinea is developed gradually during the first years until 2008 with a slight change between the period from 2002 to 2007. However from 2008, unprecedented growth of this invoice is produced. Import values rose from around \$ 250 million in 2008 to \$ 900 million in 2013 (Figure 3 ). This increase will be largely due to the massive importation of Moto during the period 2008-2013 (Figure 4). From 2013 there is a significant decline in motorcycle imports. This will be caused by the emergence of the Ebola epidemic and health restrictions on subsequent Guinean nationals (Figure 2).

\subsection{Trade Balance between Guinea and China}

The trade balance between the two countries has traditionally been negative for Guinea, it is only in 2002 that this balance began to widen to take a Pick between 2007 and 2013 (Figure 5).

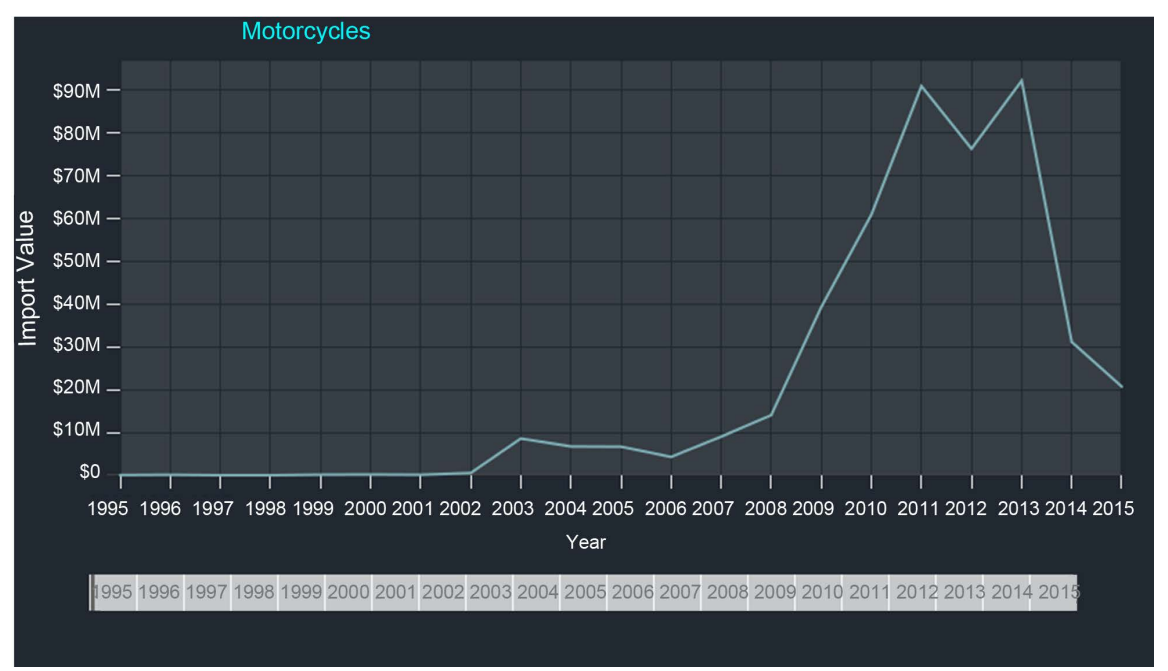

Figure 4. Motorcycle import.

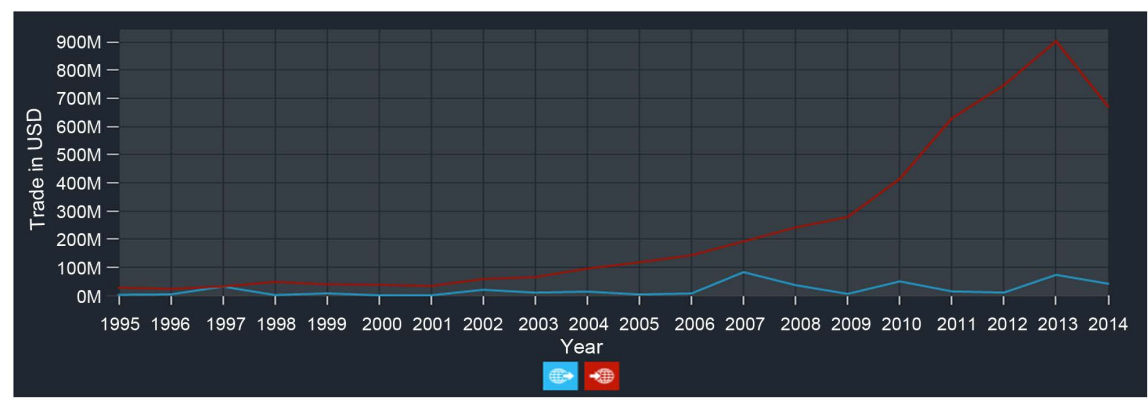

Figure 5. Trade balance between Guinea and China. Source: Calculated from Comtrade database, February 2016. 
This trend is expected to change after the revival of the giant iron mining project of Mount Simandou, which was formalized in Beijing on 28 October 2016 on the eve of the official tour of the President of the Republic of Guinea.

The project of Mount Simandou, located in the east of the country, seemed to be at a standstill after the Anglo-Australian Rio Tinto announced the pure and simple putting of this mega-mining project. A coup in the Chinese capital: Rio Tinto and Chinese Chinalco, who has been associated with the project since 2012, reached an agreement on the conditions for the transfer of all the shares from the first to the second in the development of the southern part of the country. Simandou, where the continent's largest iron ore deposit is located.

On the hydroelectric front, Guinea again turned to China International Water and Electric Corporation, which had already built the Kaléta dam (240 megawatts, \$ 446 million financed by the Chinese export-import bank China Exim Bank To 75\%), inaugurated in September 2015, to advance on the financing of the 1.3 billion dollars needed to build the one of Souapiti.

About the diplomatic visit of November 2016, the president of the Republic of Guinea said: "This is a strategic partnership that we will establish with China," said President Guineen During his visit to China in November 2016 In return for our raw materials, China will finance infrastructure: roads, airports, ports, railways, energy and agriculture.

In view of this announcement, we are inclined to believe that the import bills of Machines will increase in the coming year like its all ready started from 2007 (Figure 6), and this will be the same for iron ore exports.

\section{Conclusions}

The last years China has become an important player in the global economy, and impacting almost all the country in the world. Economic and diplomatic relationships with Guinea are evolving rapidly, and providing Guinea with an alternative source of finance and diversify its market outlets. Like every relationship, these interactions are creating both winners and losers among the concerned stakeholders in Guinea. The concern is how the authorities can find a way to increase earnings while at the same time addressing the losses, rather than count-

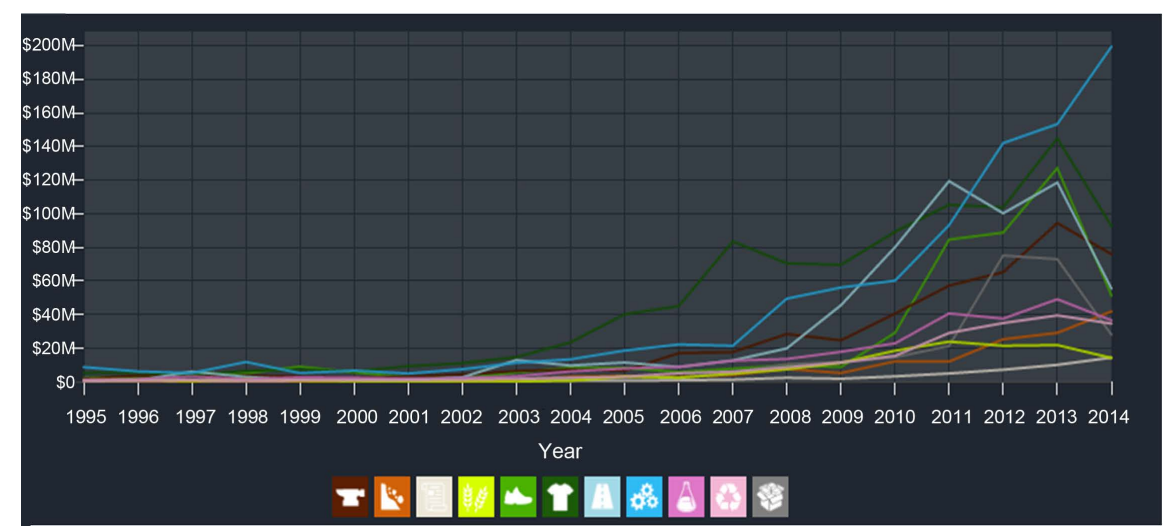

Figure 6. Imported Product from China. source: UNcomtrad database. 
ing on the rhetoric of the winning partnership, often proclaimed by Chinese leaders. Due to a surge in import from China, over the past few years, trade with China has considerably increased.

Guinea Imports from China are made up of a large variety of essentially manufactured goods, though issues of quality abound. This raises the risk of undermining the industrial sector and locking Guinea in primary activities. Exports on the other hand to China are limited to a few primary products, essentially Iron ores and Raw Wood.

There is a need for Guinea to find a way to increase and diversify exports to China, especially for products such as peanuts, coffee, fishery products, etc. and all the product that would benefit from duty-free access. In order to reduce or eliminate some of the competitive pressures on the local industry, measures must be taken to effectively reduce the fraudulent entry of Chinese products in the country to end unfair competition with local firms. Also, the Government could also protect certain strategic sectors through dialogue with China for the voluntary restriction of certain exports. Guinea is not in a position to negotiate any unilateral trade commitments with China in view of its obligations as a member of the CDEAO subregion.

As we know, no country in the world seems to have modernized or developed its economy sustainably without structurally transforming its agriculture to the point of take-off. On those, Guinea now has the opportunity to transform its agriculture and profit from the Chinese growth through their trade relations.

To take advantage of the benefits and reduce losses with Sino-Guinean trade relations, a strategic approach is essential for the establishment of a long-term vision. This vision will aim to upgrade Guinea's comparative advantages to more profitable fields of activity by increasing their technological level step by step (mass production of agricultural products, transformation of industry to high products Technologies) through learning and the adoption of best practices, while relying on the most abundant factors in each phase of development. This vision could be reached strategically by means of fiscal policies and also the reduction of the administrative approach, which acts as a brake on private initiatives.

\section{References}

[1] African Development Bank and OECD (2015) Africa Economic Outlook. http://www.africaneconomicoutlook.org/en/countries/central-africa/cameroon/

[2] Winters, L.A. and Yusuf, S. (2007) Introduction. In: Winters, L.A. and Yusuf, S., Eds., Dancing with Giants. China, India, and the Global Economy, World Bank and the Institute of Policy Studies, Washington DC and Singapore.

[3] Rodrik, D. (2006) What's So Special about China's Exports? Faculty Research Working Papers Series No. RWP06-001.

[4] China: Export of Goods from 2005 to 2015 (in Billion U.S. Dollars). https://www.statista.com/statistics/263661/export-of-goods-from-china/

[5] Statistics and Facts about Export in China. https://www.statista.com/topics/1456/export-in-china/ 
[6] Xu, W. (2008) Sino-African Relations: New Transformations and Challenges. In: Gerrero, D.-G., and Manji, F., Eds., China's New Role in Africa and the South, Fahamu and Focus on the Global South, Cape Town and Bangkok, 12-20.

[7] Kaplinsky, R. (2007) The Impact of China and India on the Sub-Saharan Africa: A Methodological Framework. A Framework Paper for AERC Project: “The Impact of Asian Drivers on Sub-Saharan Africa”, AERC, Nairobi, Kenya.

[8] Kaplinsky, R. and Morris, M. (2007) Do the Asian Drivers Undermine ExportOriented Industrialization in SSA? World Development, 36, 254-273.

[9] Ajakaiye, O. (2006) China and Africa-Opportunities and Challenges.

[10] Goldstein, A., Pinaud, N., Reisen, H. and Chen, X. (2006) The Rise of China and India: What's in It for Africa? Policy Insights, No. 19, 23-34. https://doi.org/10.1787/9789264024427-en

[11] Zafar, A. (2007) The Growing Relationship between China and Sub-Saharan Africa: Macroeconomic, Trade, Investment and Aid Links. The World Bank Research Observer, 22, 103-130. https://doi.org/10.1093/wbro/lkm001

[12] Mary-Françoise Renard (2011) China's Trade and FDI in Africa. 12-30.

[13] De Grauwe, P., Houssa, R. and Piccillio, G. (2012) African Trade Dynamics: Is China Different Trading Partner? Journal of Chinese Economic and Business Studies, 10, 15-45.

[14] Co, C.Y. and Dimova, R.D. (2014) Preferential Market Access into the Chinese Market: How Good Is It for Africa? IZA Discussion Paper No. 7908. https://ssrn.com/abstract=2389256

[15] http://english.mofcom.gov.cn/article/newsrelease/significantnews/201702/20170202 515699.shtml

[16] Khan, S.A. and Baye, F.M. (2008) China-Africa Economic Relations: The Case of Cameroon. Scoping Study for the AERC Project, The Impact of Asian Drivers on Sub-Saharan Africa. Paper No. SSC16.

[17] Ancharaz, V. and Tandrayen-Ragoobur, V. (2010) The Impact of China-Africa Trade Relations: The Case of Mauritius. 4-12.

[18] Edwards, L. and Jenkins, R. (2015) The Impact of Chinese Import Penetration on the South African Manufacturing Sector. The Journal of Development Studies, 51, 320-340.

Open Access Library

Submit or recommend next manuscript to OALib Journal and we will provide best service for you:

- Publication frequency: Monthly

- 9 subject areas of science, technology and medicine

- Fair and rigorous peer-review system

- Fast publication process

- Article promotion in various social networking sites (LinkedIn, Facebook, Twitter, etc.)

- Maximum dissemination of your research work

Submit Your Paper Online: Click Here to Submit

Or Contact service@oalib.com 